\title{
Identifikasi Pemanfaatan Kawasan Konservasi Mangrove di Wonorejo Surabaya
}

\author{
Rizki Ade Pratama dan Dian Rahmawati. ST., MT. \\ Departemen Perencanaan Wilayah dan Kota, Fakultas Teknik Sipil dan Perencanaan, Institut Teknologi \\ Sepuluh Nopember (ITS) \\ e-mail:dnrahmawati66@gmail.com
}

\begin{abstract}
Abstrak-Pemanfaatan wilayah pesisir memiliki beragam kepentingan dengan ragam kegiatan atau aktivitas yang ada dan akan menimbulkan dampak merugikan apabila terjadi ketidakselarasan dari sebuah sitem lingkungan. Suatu daerah salah satunya Kota Surabaya sendiri perlu mengendalikan dan mengawasi kegiatan dan aktivitas dari kawasan konservasi khususnya mangrove di Wonorejo Surabaya. Kawasan konservasi mangrove sendiri bukan berarti tidak memiliki nilai ekonomi. Banyaknya aktivitas dan kegiatan di kawasan tersebut. Salah satu aktivitas terbesar kawasan tersebut yaitu pariwisata. Dengan adanya kegiatan pariwisata tersebut sangat memungkinkan pengembangan kegiatan dan aktivitas lain berkembang di kawasan tersebut sehingga mengancam sistem lingkungan di kawasan konservasi. Maka dari itu, perlu mengidentifikasi pemanfaatan kawasan konservasi mangrove agar mempermudah kotrol dan pengawasan kawasan tersebut sehingga terjadi keselarasan dari sebuah sistem lingkungan. Tujuan dari penelitian ini yaitu mengidentifikasi pemanfaatan kawasan konservasi mangrove di Wonorejo Kota Surabaya. Tujuan tersebut dapat dicapai melalui pemetaan manfaat secara spasial dari kawasan konservasi mangrove dengan teknik Participatory Mapping. Adapun hasil penelitian ini yaitu terdapat 3 pemanfaatan mangrove yaitu manfaat hasil hutan ikutan, manfaat perikanan dan manfaat rekreasi dan pariwisata.
\end{abstract}

Kata Kunci-Pemanfaatan Wilayah Pesisir, Participatory Mapping, Kawasan Konservasi Mangrove.

\section{PENDAHULUAN}

$\mathrm{P}$ EMANFAATAN sumberdaya wilayah pesisir dapat menciptakan kesejahteraan yang optimal dan berkelanjutan, manakala hubungan antar sistem dalam wilayah tersebut dapat terpelihara dengan baik. Pada kenyataannya, masyarakat atau penentu kebijakan sering memandang suatu sumberdaya pesisir seperti kawasan konservasi mangrove sebagai lahan marginal yang harus dikonversi menjadi penggunaan lainnya [1].

Salah satu kawasan konservasi di sebelah timur Kota Surabaya adalah kawasan konservasi hutan mangrove di Wonorejo. Pada tahun 1985, kawasan hutan mangrove adalah 3500 Ha. Pada tahun 2012, Luas hutan mangrove menurun menjadi 750 Ha. Tetapi saat ini sekitar 223,8 Ha, sedangkan daerah ini adalah tempat untuk 29 spesies tanaman mangrove yang perlu dilestarikan [2]. Ekosistem mangrove sering kali dianggap sebagai sumberdaya milik umum yang dimanfaatkan oleh siapa saja tanpa memperhatikan aspek kelestariannya. Pemanfaatan berlebihan mengakibatkan sumberdaya mangrove semakin menipis dan kemampuan ekosistem untuk menyediakan jasa-jasa lingkungan semakin menurun [3]. Pembangunan ekonomi tanpa diimbangi dengan perlindungan sumber daya alam akan berbalik mengancam kehidupan umat manusia dan seluruh sistem kehidupan lainnya. Hal tersebut berarti, pembangunan tersebut hanya dinikmati sesaat, tidak dapat dinikmati oleh generasi berikutnya akibat hancurnya ekologi [4]. Hal tersebut sangat tidak sesuai dengan prinsip pembangunan berkelanjutan dimana ssosial, ekologi dan ekonomi harus saling bersinambungan. Pembangunan berkelanjutan secara luas dikenal sebagai pembangunan yang memenuhi kebutuhan masa kini tanpa mengurangi kemampuan generasi masa depan untuk memenuhi kebutuhan mereka sendiri [5].

Terlepas dari permasalahan di atas, terdapat potensi dari mangrove yang ada di Wonorejo Surabaya yaitu pemanfaatan sebagai Ekowisata dan diversifikasi ekonomi seperti bahan baku sirup, bahan makanan dan obat-obatan. Masyarakat membentuk Ekowisata Mangrove sebagai upaya pemanfaatan di bidang pariwisata yang di dalamnya terdapat ekowisata perahu, pos pantau dan pemancingan ikan di daerah Wonorejo. Selain hal tersebut, mangrove (Sonneratia) dimanfaatkan sebagai bahan sirup mangrove. Potensi tersebut merupakan konservasi terhadap ekosistem yang ada. Upaya tersebut dilakukan untuk melindungi, melestarikan dan memanfaatkan ekosistem untuk menjamin keberadaan, ketersediaan dan kesinambungannya sehinnga fungsi ekosistem dan produktivitas perariran laut semakin meningkat [4].

Banyaknya kegiatan dan aktivitas di kawasan tersebut mengancam sebuah sistem lingkungan di kawasan konservasi. Suatu daerah salah satunya Kota Surabaya sendiri perlu mengendalikan dan mengawasi kegiatan dan aktivitas dari kawasan konservasi khususnya mangrove di Wonorejo Surabaya. Kawasan konservasi sendiri bukan berarti tidak memiliki nilai ekonomi. Maka dari itu, perlu mengidentifikasi pemanfaatan kawasan konservasi mangrove agar mempermudah kotrol dan pengawasan kawasan tersebut sebelum peerkembangan kegiatan dan aktivitas mengancam sebuah sistem lingkungan.

\section{METODE PENELITIAN}

\section{A. Jenis dan Pendekatan Penelitian}

Adapun jenis penelitian yang digunakan merupakan gabungan dari penelitian deskriptif. Penelitian deskriptif merupakan jenis penelitian yang mencari hubungan antar 
beberapa variabel terkait [6].

\section{B. Variabel Penelitian}

Penentuan variabel penelitian dilakukan berdasarkan hasil dari kajian pustaka yang telah dilakukan sebelumnya dengan melakukan penyesesuaian kondisi eksisiting yang terdapat pada wilayah penelitian. Adapun variabel penelitiannya antara lain manfaat kayu, manfaat hasil hutan ikutan, manfaat perikanan serta manfaat rekreasi dan pariwisata.

C. Pemetaan Manfaat Secara Spasial dari Kawasan Konservasi Mangrove di Wonorejo Kota Surabaya

Pada tahap ini menggunakan metode participatory mapping, dimana merupakan analisis proses penggambaran masyarakat yang sistematik serta melibatkan pengumpulan data dan informasi mengenai masyarakat terkait pemanfaatan langsung hutan mangrove. Partisipasi masyarakat merupakan salah satu proses pembangunan masyarakat dengan melibatkan masyarakat dalam prosesnya [7]. Dalam penerapannya, terdapat beberapa prinsip dasar yang menjadikan participatory mapping berbeda dengan teknik lainnya, yaitu [8]:

1. Masyarakat dipandang sebagai subjek bukan objek.

2. Peneliti memposisikan dirinya sebagai insider bukan outsider

3. Pemberdayaan dan partisipatif masyarakat dalam menentukan indikator sosial (indikator evaluasi partisipatif).

Adapun langkah yang perlu ditempuh dalam melakukan analisis participatory mapping ini adalah sebagai berikut:

1. Menentukan wilayah sasaran dengan pemetaan luas wilayah

2. Mendekati dan menjalin komunikasi dengan masyarakat setempat

3. Melakukan pendataan mengenai keberadaan lokasi kegiatan serta potensi yang dimilikinya. Adapun teknik pengambilan data yang digunakan adalah dengan membuat pemetaan di atas kertas (menggunakan alat tulis)

\section{HASIL DAN DISKUSI}

Dalam memetakan manfaaat kawasan konservasi mangrove di Wonorejo Kota Surabaya dilakukan dengan menggunakan metode Participatory Mapping. Participatory Mapping dilakukan dengan tujuan untuk mengetahui luasan dan manfaat apa saja yang ada di kawasan konservasi mangrove yang merupakan variabel dari penelitian ini.

Dalam Participatory Mapping, input data yang digunakan sebagai masukan merupakan variabel manfaat yang ada di kawasan konservasi mangrove. Variabel tersebut diperoleh dari hasil sintesa pustaka yang dilakukan pada pembahasan bab sebelumnya. Akan tetapi, tidak semua variabel yang digunakan untuk Participatory Mapping. Variabel-variabel tersebut merupakan manfaat ekonomi pemanfaatan mangrove yaitu manfaat kayu, manfaat hasil hutan ikutan, manfaat serta manfaat rekreasi dan pariwisata. Participatory Mapping yang dilakukan terhadap responden yang benar-benar mengetahui manfaat yang ada di kawasan konservasi mangrove. Responden tersebut terdiri dari 3 orang yang merupakan pengelola kawasan konservasi mangrove di Wonorejo. Dari keterangan 3 responden tersebut, saat ini sudah tidak terdapat lagi pemanfaatan kayu yang ada di kawasan konservasi mangrove di Wonorejo Surabaya. Hal tersebut dikarenakan sudah dilarang karena termasuk kegiatan pembalakan kayu, Sehingga variabel pemanfaatan kayu tidak memiliki nilai di kawasan tersebut. Sedangkan variabel manfaat hasil hutan ikutan, manfaat perikanan serta manfaat rekreasi dan pariwisata memang ada pada kawasan konservasi mangrove Wonorejo Surabaya. Ketiga responden tersebut memetakan pemanfaatan mangrove tersebut dengan baik dan tidak ada perbedaan terhadap lokasi variabel pemanfaatan mangrove. Untuk variabel manfaat hasil hutan ikutan terdapat pemanfaatan mangrove sebagai sirup dan sari buah yang dihasilkan buah dari jenis mangrove Sonneratia caseolaris. Lokasi mangrove yang termanfaatkan sebagai hasil hutan ikutan berada di sebelah utara kawasan mangrove tepatnya di sekitar pinggir sungai dan mangrove disekitar jogging track Mangrove Information Center (MIC) seperti pada Gambar 1. Untuk variabel manfaat perikanan terdapat pemanfaatan mangrove sebagai hasil kepiting yang terdapat di pinngir sungai dan laut serta hasil bandeng dan udang yang terdapat pada mangrove sekitar tambak seperti pada Gambar 2. Untuk variabel manfaat rekreasi dan pariwisata terdapat disepanjang mangrove sebelah utara sepanjang Mangrove Information Center (MIC), jogging track, mangrove yang dilalui perahu hingga pos pantau dan gazebo ekowisata mangrove Wonorejo seperti pada Gambar 3. Hasil Participotory Mapping dari variabel-variabel tersebut diketahui luasannya yang dihitung melalui aplikasi ArcGIS 10.1. Untuk lebih jelasnya terlihat pada Tabel 1 .

Tabel 1.

Luas Peemanfaatan Kawasan Konservasi Mangrove

\begin{tabular}{clc}
\hline \hline No & \multicolumn{1}{c}{ Variabel } & Luas (Ha) \\
\hline 1 & Nilai/harga kayu & - \\
2 & Nilai/harga hasil hutan ikutan & 1,98 \\
3 & Nilai/harga perikanan & 39,29 \\
4 & Manfaat Rekreasi dan Pariwisata & 14,46 \\
\hline \hline
\end{tabular}

Sumber : Penulis, 2016

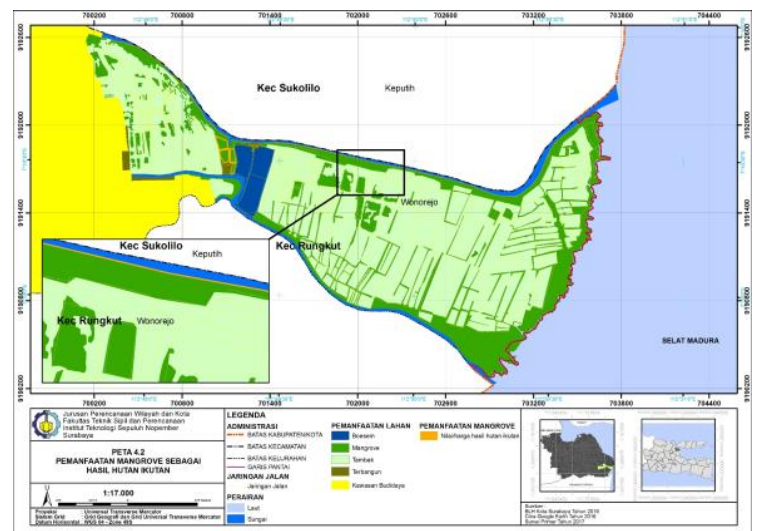

Gambar 1. Peta Pemanfaatan Mangrove sebagai Hasil Hutan Ikutan. 


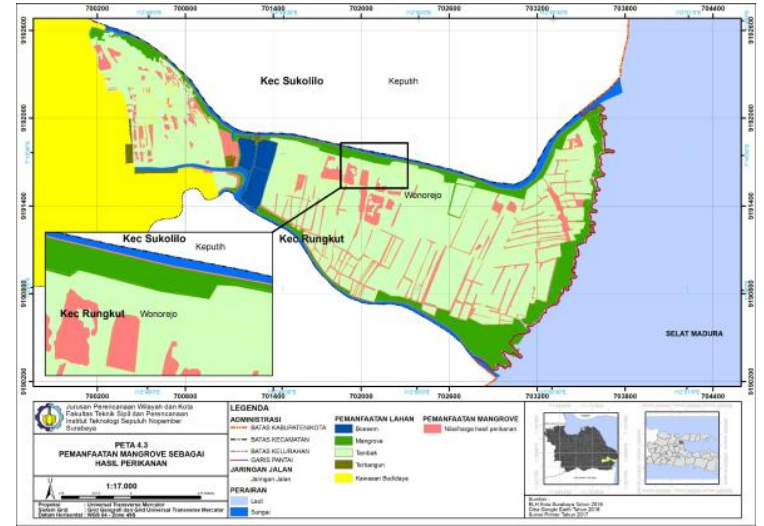

Gambar 2. Peta Pemanfaatan Mangrove sebagai Hasil Perikanan.

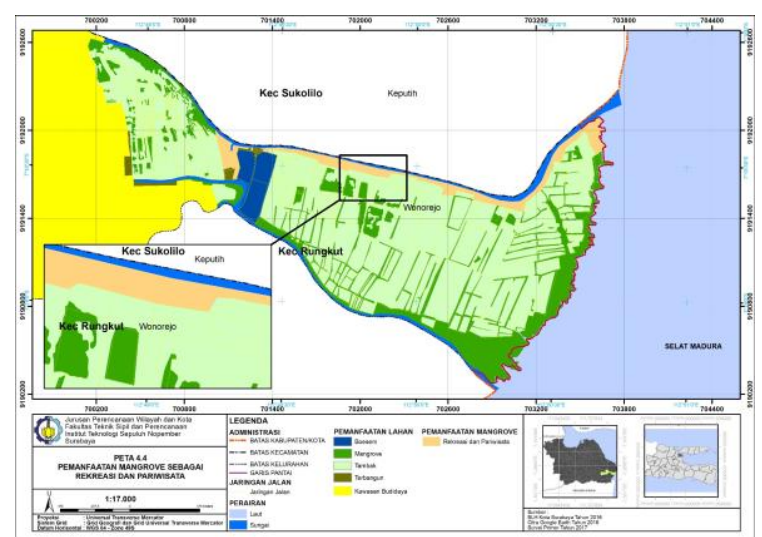

Gambar 3. Peta Pemanfaatan Mangrove sebagai Rekreasi dan Pariwisata.

\section{KESIMPULAN}

Berdasarkan hasil analisis yang telah dilakukan, maka dapat diperoleh kesimpulan dari penelitian ini yaitu variabel-variabel yang terdapat pada pemanfaatan kawasan konservasi mangrove di Wonorejo Surabaya adalah manfaat hasil hutan ikutan, manfaat perikanan serta manfaat rekreasi dan pariwisata. Adapun luasan pemanfaatan pada masing-masing variabel adalah sebagai berikut : manfaat hasil hutan ikutan sebesar 1,98 Ha; manfaat perikanan sebesar 39,28 Ha serta manfaat rekreasi dan pariwisata sebesar 14,46 Ha.

\section{DAFTAR PUSTAKA}

[1] N. Harahab, Penilaian Ekonomi Ekosistem Hutan Mangrove \& Aplikasinya dalam Perencanaan Wilayah Pesisir. Yogyakarta: Graha Ilmu, 2010.

[2] D. Rahmawati, "Mangrove Conservation Area in Wonorejo. Presentasi disajikan dalam CommTECH Camp Highlight 2016: Strands Of Sands Surabaya," Institut Teknologi Sepuluh Nopember, 2014.

[3] L. S. Hiariey, "Identifikasi Nilai Ekonomi Ekosistem Hutan Mangrove di Desa Tawiri, Ambon," 2009. [Online]. Available: http://jurnal.ut.ac.id/JOM/search/authors/view?firstName=Lilian\& middleName $=$ Sarah $\&$ lastName $=$ Hiariey\&affiliation $=$ Universitas Terbuka\&country=ID [25 Oktober 2016.

[4] S. Diposaptono, Membangun poros maritim dunia: dalam perspektif tata ruang laut. Jakarta: Kementerian Kelautan dan Perikanan, Direktorat Jenderal Kelautan, Pesisir, dan Pulau-Pulau Kecil, Direktorat Tata Ruang Laut, Pesisir, dan Pulau-Pulau Kecil, 2016.

[5] D. Raissa, Devina Rahma. Setiawan, Rulli Pratiwi. Rahmawati, "Identification of Indicators Influencing Sustainability of Minapolitan Area in Lamongan Regency," 2014. [Online]. Available:

http://www.sciencedirect.com/science/article/pii/S18770428140427 00 .

[6] A. Hidayat, Metode Penelitian dan Teknik Analisis Data. Jakarta: Salemba Medika, 2009.

[7] H. Adimihardja, K dan Hikmat, Participatory Research Appraisal:Pengabdian dan Pemberdayaan Masyarakat. Bandung, 2003.

[8] D. Cahyani, Reni dan Rahmawati, "Peningkatan Partisipasi Masyarakat Dalam Perbaikan Sanitasi Permukiman Kelurahan Putat Jaya Kota Surabaya,” J. Tek. ITS, vol. 4, 2016. 